\title{
Local determinants influencing stream water quality
}

\author{
Aadil Hamid ${ }^{1} \cdot$ Sami Ullah Bhat ${ }^{1} \cdot$ Arshid Jehangir $^{2}$ \\ Received: 24 June 2017 / Accepted: 23 September 2019 / Published online: 3 December 2019 \\ (c) The Author(s) 2019
}

\begin{abstract}
It is important to have reliable information on various natural and anthropogenic factors responsible for influencing and shaping stream water quality parameters as long as water resource conservation and management planning are concerned from the local to global scale. Daunting environmental pressures at multiple scales makes this necessity more pronounced owing to the special role of stream ecosystems in providing regional services. Understanding how coupled effect of natural and anthropogenic factors controls stream water quality parameters and how the relationships change over space and time will help policy makers and resource managers to target appropriate scales at watershed level for the quality management of stream waters. This paper sums up the information on various natural and anthropocentric factors as major determinants responsible for conditioning and shaping stream water quality parameters and their simultaneous influence on biota and its use.
\end{abstract}

Keywords Stream $\cdot$ Natural $\cdot$ Anthropogenic $\cdot$ Factors $\cdot$ Nitrate $\cdot$ Phosphorus

\section{Introduction}

Various factors influence the composition of stream water, causing variation from place to place (Ahearn et al. 2005; Sharma et al. 2016). The quality of river and stream water is very sensitive to anthropogenic influences (urban, industrial and agricultural activities, increasing consumption of water resources) as well as natural processes (changes in precipitation inputs, erosion, weathering of earths crustal material) degrade the surface waters and impair their use for drinking, industrial, agricultural, recreation or other purposes (Jarvie et al. 1998; Ramírez et al. 2014; Kim and An 2015). All of the constituents of river water originate from dissolution of the earth's rocks. The dissolution of rocks in the catchment area is a major determinant of river water chemistry locally as well, but this varies with geology and with the magnitude of inputs through the amount, type and distribution of precipitation, surrounding vegetation, catchment

Aadil Hamid

aadilenvsc@gmail.com

1 Aquatic Ecology Laboratory, Department of Environmental Science, University of Kashmir, Srinagar 190006, India

2 Terrestrial Ecology Laboratory, Department of Environmental Science, University of Kashmir, Srinagar 190006, India hydrology and land use (Hynes 1975; Hornung et al. 1990; Salmiati et al. 2017). Spatial variation is a functional attribute of various ecological factors encompassing the incoming tributaries, longitudinal changes in catchment land use, soil characteristics or geology (Townsend et al. 1983; Meyer et al. 1988; Schultz et al. 1993). However, a temporal fluctuation is mostly due to seasonal shifts in biological activity in the catchment, variation in weather and changes in the hydrological pathways by which runoff reaches the river (Likens et al. 1977; Sutcliffe and Carrick 1983; Burns et al. 1998). Materials are concentrated by evaporation and altered by chemical and biological interactions within the stream. Stream water is found to vary considerably in chemical characteristics contrary to seawater, which is quite constant everywhere and can be approximated with an artificial standard (Livingstone 1963; Allan 1995; Collins and Jenkins 1996; Hornbeck et al. 1997; Jarvie et al. 1997; Fraser and Williams 1997; Lovett et al. 2000; Nakagawa and Iwatsubo 2000; Turner et al. 2003a, b; Ahearn et al. 2004; Davies et al. 2005). The present paper provides a detailed account of various natural and anthropogenic factors responsible for conditioning and shaping water quality in stream ecosystems. Clear and concise information on water quality can help in other water assessments. 


\section{Water quality parameters}

\section{Temperature}

According to Smith (1981), the annual thermal regime of a river is one of the most significant water quality parameters, being a key component in determining the distribution of aquatic organisms. Furthermore, the author opined that most of the physical, chemical and biological properties of water are temperature dependent. Temperature being one of the most important ecological factors is of great importance in streams (van Vliet et al. 2011; Beechie et al. 2013). Several workers have kept a stretch of stream under observation for a period of time from seasonal to diurnal cycles and have found that superimposed upon the seasonal changes there are diurnal cycles in temperature (Edington 1966; Webb and Walling 1985). Annual temperature range in temperate streams is usually between 0 and $25^{\circ} \mathrm{C}$ (Matthews and Zimmerman 1990). These may amount to $6{ }^{\circ} \mathrm{C}$ in small streams in summer time (Edington 1966), with lower values in large rivers. Large rivers and streams at some substantial distance from their sources are usually at more or less in a proportional equilibrium with the mean monthly air temperature at the point of measurement (Hynes 1970). In winter time, however, ice and snow form an insulating layer, and even in extreme climates such as that of Alaska, the water temperature does not fall below $0{ }^{\circ} \mathrm{C}$ (Sheridan 1961). In spring season, snow melt water may keep the temperature below that of the air for quite some time (Sheridan 1961). Many workers have shown that the summer time temperature of water increases downstream in such a way that the rise is more or less proportional to the logarithm of the distance from the source (Hynes 1970). Minckley (1963) found that $5 \mathrm{~km}$ from its source in a large spring, the temperature of Doe Run, Kentucky, varied from $6.1{ }^{\circ} \mathrm{C}$ in winter to $20{ }^{\circ} \mathrm{C}$ in summer, while the temperature at the source remained between 13 and $13.5^{\circ} \mathrm{C}$ at all seasons. Streams flowing underground or through man-made culverts may be cooled or warmed in the process according to the season, and wind or shade may cause considerable changes. Macan (1958) reported a fall from 21.6 to $14{ }^{\circ} \mathrm{C}$ in a small stream flowing through woodland on an east-flowing slope during a period of easterly wind, and Edington (1966) observed that shaded reaches in streams in northern England are warmer in winter and cooler in summer, and reach their maximum temperature later in the year, an exposed reaches. Numerous studies have demonstrated that the presence of riparian woodland can decrease diurnal variability, mean and maximum stream temperatures (Crisp and Howson 1982; Malcolm et al. 2008; Brown et al. 2010; Roth et al. 2010; Imholt et al. 2012; Garner et al. 2014a, b) or, conversely, that forest removal results in temperature increases (Poole and Berman 2001; Macdonald et al. 2003; Rutherford et al. 2004; Danehy et al. 2005; Moore et al. 2005). Meier et al. (2003) while modeling the effect of water diversion on the temperature of mountain streams reported that the reduction in discharge from 15.5 to $4.9 \mathrm{~m}^{3} \mathrm{~s}^{-1}$ causes a downstream temperature increase of up to $3.7^{\circ} \mathrm{C}$. The high positive correlation between air and water temperature in streams increasing with distance has been observed by other workers as well (Zappa et al. 2000; Smith et al. 2001; Uehlinger et al. 2003).

In contrast to lakes, rivers normally show little stratification because of their turbulent flow (Hynes 1970). There are reports that streams may freeze altogether. Kamler (1965) reported freezing of streams in the Tatra Mountains in southern Poland. Hynes (1970) reported the same in small streams on the Pennines in England. Underwater ice being of far greater biological importance forms during clear cold nights, and only in water which is not frozen over. Reports of the air temperature needed to cause its formation vary from -15.6 to $-23{ }^{\circ} \mathrm{C}$ (Needham and Jones 1959). Stream temperature is spatially and temporally variable (Hynes 1960; Biggs et al. 1990 ) and is a function of the source water temperature and its transport time (Angelier 2003). Temperatures may be staying steady in large rivers with low flow speeds, but can go up and down quickly in steep shallow streams. Seasonal variation also results from changes in the hydrologic regime (Angelier 2003) and air temperature (Smith 1981). There is a proof that air temperature can be used to project influence of climate change on stream temperatures (Arismendi et al. 2014). Smith (1981) found that stream temperatures in Great Britain were highly correlated to air temperature. In addition, other studies show that elevation, riparian vegetation and channel width effect stream temperature (Osborne and Wiley 1988; Gregory et al. 1991). These results indicate that readily available landscape variables, such as elevation, air temperature and riparian condition (Platts 1979; Vannote and Sweeney 1980), may explain some variability in stream temperature. Change in river temperature is also in response to flow reductions (water abstractions) and releases below reservoirs have received increasing interest (Webb et al. 2008). Artificial reductions or increases in flow alter the assimilative thermal capacity of the river, resulting in an increased occurrence of high-temperature events and increases in temperature minima, respectively (Webb et al. 2008; Hannah and Garner 2015).

\section{Flow/discharge}

The natural flow regime in rivers is now extensively considered essential to satisfy natural riverine ecosystems, as it maintains a wide range of abiotic and biotic environments and processes including material delivery, routing and 
deposition that native ecosystems have adapted to (Naiman et al. 2000; Arthington et al. 2010). The flow regime is considered a 'master variable' as it affects riverine ecosystems directly (e.g., hydraulic habitat) and indirectly (physiology of individuals) (Resh et al. 1988; Kiernan and Moyle 2012). Indirect control mechanisms involve interactions with other environmental factors, such as sediment and air temperature (Caissie 2006; Yarnell et al. 2010), which are also vital to a river's ecological functioning. Though the flow regime is only one factor influencing a river's ecosystem (Olden and Naiman 2010), it is well established that the alteration of flow regimes often has negative consequences to native freshwater species and ecosystem functioning. The documented research suggested that the flowing water regime shows regional patterns that are determined primarily by river size and by geomorphic heterogeneity in climate, geology, topography and vegetative cover (Poff et al. 1997; Garnier and Mouchel 2013; Rheinheimer and Viers 2014). Both reservoirs and climate change alter flow regimes. The specific effects of reservoirs, dam operations and water diversions on flow regimes vary widely (Grantham et al. 2010). The variability is dependent on not only the water management scheme and specifics of the built infrastructure but also the antecedent environmental conditions and a range of context-dependent factors.

Hydrological variations play a major role in structuring the biotic diversity within river ecosystems as it controls key habitat conditions within the river channel, the floodplain and the hyporheic zones (Poff and Ward 1989; Lusardi et al. 2016). Nakamura (1989) believed that local geomorphology has a marked effect on disturbance characteristics by influencing temporal patterns in flow, discharge magnitude and substrate composition. The author suggested that through this effect on the frequency, intensity and severity of disturbance geomorphology can be expected to play an important role in the temporal persistence of invertebrate communities. Gregory et al. (1991) stated that the riparian vegetation is of prime importance in biodiversity conservation and aesthetic considerations in addition to its role in stabilizing channel and floodplains, and to control the amount of sediment, nutrients and agricultural pollutants reaching rivers from floodplains and hill slopes. The studies made by Kondolf (1997) suggested that in-stream mining directly alters the channel geometry and bed elevation and may involve extensive clearing, diversion of flow, stockpiling of sediments and excavation of deep pits or gravel bar skimming. In all cases, the preexisting channel morphology is disrupted and a local sediment deficit is produced. Kondolf (1997) further emphasized that in-stream gravel mining may induce channel incision, bed coarsening and lateral channel instability, alteration of inter-gravel flow paths and thus degradation of salmonid habitat. Parfitt and Buer (1980) have concluded, while working on upper Sacramento River, California, as soon as the site was put to massive extraction of gravel from the riverbed, combined with trapping of bed load sediment behind Shasta Dam upstream and release of hungry water. These anthropogenic activities resulted in coarsening of the bed in such a way that spawning habitat of Chinook salmon was virtually eliminated in the reach. Poff et al. (1997) identified five critical components of stream flow regime's process including magnitude, frequency, timing of flow (predictability) and the rate of change or flashiness that regulate ecological conditions. According to Sabater and Elosegi (2013) and Dynesius and Nilsson (1994), river flow has been subject to human modifications through increase in impervious areas in drainage basin, flood control of dikes, storage and abstraction of water for irrigation, drinking water and power production. Further, authors have enlisted various disturbing effects of river water diversion for the above-said purposes on biota and riparian vegetation, including prevention and movement of biota, reductions in flow volume, changes in seasonal flow regimes, changes in downstream temperatures and nutrients, reduction in sediments and changes in downstream channel morphology, besides shift in species interactions and elimination of aquatic species, therefore altering the food web.

\section{Light}

Light is one of the most prominent abiotic factors that limit primary production in lotic ecosystem (Elwood et al. 1981). Primary production in many lotic systems that are bounded by well-developed plant communities appears to be affected by low light levels and can intercept $>95 \%$ of incoming solar radiation, reducing photon density (Fisher and Likens 1973; Vannote et al. 1980). Minckley (1963) made a series of light measurements at the surface of Doe Run, Kentucky, a stream whose banks were still in fairly natural state. He further emphasized that the illumination reached a maximum in April as the sun rose higher in the sky, but it then fell steadily, as the leaves opened on the trees, to levels compared with those of midwinter. Indeed, in the narrow wooded gorge at the head of the stream the intensity of light at the stream surface was at its minimum during the summer, and it rose during the late autumn after leaf-fall. Hynes (1970) concluded that in unaltered streams, the periods of maximum illumination are spring and fall and that in the tropics the stream bed was always a fairly dark place before man cleared the riparian vegetation. $\mathrm{He}$ emphasized that it should not be forgotten that these are the conditions under which the biota of running water evolved. Hill et al. (1995) who studied the response of periphyton and grazing snails (Elimia clavaeformis) to summer shade in White Oak Creek in Tennessee deciduous forest observed that snails at normal densities harvested periphyton biomass to low levels irrespective of light regimes, but periphyton

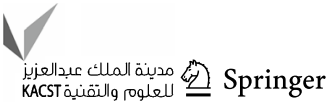


was higher at the open sites where snails grew faster and accrued more lipid. Hornbach et al. (2015) while examining the impact of riparian vegetation and season on stream metabolism of Valley Creek, Minnesota, viewed that the stream was heterotrophic regardless of the kind of riparian vegetation. However, the nearness of a forested buffer zone support discouraged gross primary production (GPP) and furthermore brought about lower (less negative) ecosystem respiration (ER) and net biological system respiration (ER) and net ecosystem production (NEP).

\section{Conductivity}

Conductivity is a good measure of concentration of charged ions in waters and is strongly influenced by landscape-scale conditions. The geology in the catchment is the source of the ions that act as conductors of electricity (Cunningham et al. 2010; Olson 2012). Rock weathering, other natural sources and anthropogenic drivers account for majority of the dissolved ions in river water (Berner and Berner 1987). According to Golterman (1975), dissolved ions exhibit two patterns 1 . It may decline with the increase in discharge and 2. or it may not change greatly with fluctuations in discharge. In addition to the above-described patterns, ions have been found to increase the concentration with the increase in discharge. Urban and agricultural land uses have been shown to increase conductivity levels (Wang and Yin 1997; Gray 2004). In addition to urbanization, agriculture is also a significant human activity that affects water quality, because it culminates in an increased input of sediments, nutrients and pesticides, which beyond water quality also affect the habitat structure and biological community (Allan 2004). It has been established that there are seasonal differences in conductivity that generally result from a negative relationship with discharge volume (Caruso 2002; Gray 2004). The higher values of EC and TDS are the indicators of higher ionic concentrations, probably due to the high anthropogenic activities in the region and geological weathering conditions acquiring high concentrations of the dissolved minerals (Costello et al. 1984). The local anthropogenic activities could be the discharges from intensive and prolonged agricultural activities (fertigation and chemigation) and discharges from industrial and domestic wastes. Agricultural activities introduce ions and metals from fertilizers and other agrochemicals (Clenaghan et al. 1998; Laar et al. 2011a, b).

In most rivers and streams, the turbulent mixing ensures a uniform distribution of dissolved substances, although small, temporary discontinuities may occur in pools and deep places. In some large rivers, however, lateral differences caused by the entry of tributaries often persist over long distances as the inflowing water tends to follow the bank on which it entered. This has been observed in several rivers in former USSR (Shadin 1956). The water of the Amazon, which is rich in electrolytes and has a high electrical conductivity, except at times of high water caused by heavy rains, is distinguishable from the water of the Rio-Negro, which is always poor in electrolytes, for about $100 \mathrm{~km}$ below the confluence of these two great rivers, and the same applies to the Apuro and Caroni Rivers for $40 \mathrm{~km}$ below their conjunction to form the Orinoco (Gessner 1961). Total concentration of dissolved salts varies with discharge and is generally higher at times of low flow. It also generally increases downstream as larger and more varied landscape drain into the water course. This has been shown to occur in the Great Berg River in South Africa (Harrison and Elsworth 1958) and the Ohio (Woods 1965), and it doubtless occurs in most rivers (Livingstone 1963; Hynes 1970; Allan 1995).

Glacier-fed streams and rivers are consistently cloudy and appear as pale-colored streaks on distant mountain landscapes and in heavily cultivated areas such as East Africa, the American Middle West and southern Ontario. Small streams are slightly turbid even at times of very low discharge (Hynes 1970). At times of low water, however, most streams and rivers are normally fairly clean, although never as lakes, and they become turbid during floods when great amounts of suspended matter may be carried. In the middle Mississippi, for example, Dorris et al. (1963), who made a long series of measurements, found a good relationship between the discharge and the turbidity, and this is a fairly general phenomenon (Hynes 1970).

\section{Dissolved gases}

Oxygen and carbon dioxide occur in river water in significant amounts. Occurrence of these major dissolved gases is influenced by partial pressure, temperature, salinity, respiration and photosynthesis (Allan 1995; Wetzel and Likens 2000). In addition to the above given factors, carbon dioxide concentration is influenced by groundwater inflows which are substantially enriched with carbon dioxide (Allan and Castillo 2007; Wetzel and Likens 2000). Diffusion of oxygen across air-water interface tends to moderate changes in dissolved oxygen concentrations in streams. For streams having high surface area-to-volume ratio, diffusion becomes the major component in the regulation of in-stream oxygen concentration (Wilcock et al. 1995). The solubility of oxygen is reduced at higher elevations due to lower atmospheric pressure and also due to increase in salinity, by about $20 \%$ in normal seawater (Allan 1995).

Welch (1952) pointed out that under natural conditions, the running waters typically contain relatively high concentration of dissolved oxygen tending toward saturation. According to the documented research, the concentration of dissolved oxygen in the rivers is perhaps of the greatest importance to the survival of the aquatic organisms (Wetzel and Likens 2000; Allan and Castillo 2007). Dissolved 
oxygen (DO), a regulating parameter in stream ecology (Hynes 1960; Dauer et al. 2000; Chang 2002), is related to the biological oxygen demand in the stream. As organic matter increases, decomposition rates rise. Microbial biomass increases in response to the addition of nutrients, and more oxygen is consumed. Oxygen is slowly replenished by atmospheric uptake, photosynthetic additions and the turbulent mixing of oxygen and water and in unpolluted headwater streams. DO concentration in water is inversely related to water temperature (Hynes 1960). Inputs from agricultural areas, such as fertilizers and animal manure, as well as sewage effluents from urban areas, are a common source of nutrients in streams (Sheets 1980). In small turbulent streams, the oxygen content is normally near or above saturation. Hall (1955), during his lengthy study of the chemistry of small forest streams, recorded the values that ranged from 100 to $129 \%$ saturation. In fact, even in torrential stream the oxygen content varies seasonally and from source to mouth. DO levels as low as $2.35 \mathrm{mg} \mathrm{L}^{-1}$ (at $0{ }^{\circ} \mathrm{C}$ ) have been recorded in the River Oka in March, although they rise somewhat before the ice breaks up, presumably because of increasing photosynthesis caused by increasing light in the spring (Shadin 1956). In many streams, there is likewise a diurnal variation in oxygen content. In many places where extensive diurnal variation has been observed, there were dense growth of aquatic plants, e.g., in several rivers in England where the phenomenon was first described (Butcher et al. 1937; Butcher 1940), and it is often particularly associated with pollution which encourages algal growth in the presence of a fairly high oxygen demand (Schmassmann 1951). But even in the absence of pollution, as in the English River Yare, variations up to $10 \mathrm{mg} \mathrm{L}^{-1}$ during $24 \mathrm{~h}$ have been observed (Owens and Edwards 1964). In large rivers, like the Mississippi and the Amazon, high water is accompanied by lowered oxygen concentrations, and these are brought about by the wash-in of organic matter and the decrease in photosynthesis caused by turbidity (Gessner 1961). High dissolved oxygen was recorded during winter season which may be due to high photosynthetic rate of phytoplankton communities in clear water that results in higher values of dissolved oxygen (Sharma and Rathore 2000; Ravindra et al. 2003). Higher dissolved oxygen in winter season and lower oxygen in monsoon were also recorded in Haraz River in Iran (Pejman et al. 2009), many rivers of Gangetic plain, India (Rani et al. 2011), and several rivers of the Central Himalayas including the Chandrabhaga River (Sharma and Sharma 2007) and the Tons River (Sharma et al. 2009).

Carbon dioxide $\left(\mathrm{CO}_{2}\right)$ concentrations in stream water are predisposed not only by atmospheric diffusion and in stream metabolism but also by groundwater inflows, which commonly are enriched with $\mathrm{CO}_{2}$ due to soil respiration throughout catchment (Allan and Castillo 2007). In addition to physical processes, two important biological processes including photosynthesis and respiration alter the concentration of $\mathrm{CO}_{2}$. Carbon dioxide $\left(\mathrm{CO}_{2}\right)$ in high concentrations is fairly rapidly lost both to the atmosphere and by interactions with calcium carbonate. In Walker Branch, Tennessee, stream water was always supersaturated with respect to the atmosphere and so outgassing occurred at all times (Jones and Mulholland 1998). Diel shifts in dissolved $\mathrm{CO}_{2}$ can be large in highly productive lowland streams that support dense growths of macrophytes and microbenthic algae (Rebsdorf et al. 1991). Midday $\mathrm{pH}$ can increase by as much as 0.5 units owing to $\mathrm{CO}_{2}$ and $\mathrm{pH}$ interdependence. Rivers receiving significant amount of organic load, outgassing of $\mathrm{CO}_{2}$ is unable to compensate for excess $\mathrm{CO}_{2}$ generated by microbial respiration because the partial pressure of $\mathrm{CO}_{2}$ $\left(\mathrm{pCO}_{2}\right)$ in the water column can exceed that of the atmosphere by as much as 2-5 times (Small and Sutton 1986; Rebsdorf et al. 1991).

Neel (1951) and Minckley (1963) showed that in small streams in Kentucky, pools and small man-made impoundments reduce the oxygen and increase the carbon dioxide content in water as it passes through them. We can, therefore, assume that the rougher the stream bed, the more rapid the restoration of equilibrium and the more stable the environment in respect of dissolved gases (Hynes 1970). Higher levels of free carbon dioxide (free $\mathrm{CO}_{2}$ ) throughout the study period, possibly because of groundwater inflows, are considerably enriched by $\mathrm{CO}_{2}$ due to soil respiration throughout the catchment (Mulholland 2003). The lower free $\mathrm{CO}_{2}$ concentrations are related to higher $\mathrm{pH}$, shallow depth and clear water (Allan and Castillo 2007). Summer high and winter low free $\mathrm{CO}_{2}$ concentrations attested to the typical inverse relationship of $\mathrm{pH}$ and free $\mathrm{CO}_{2}$ (Tucker 1984; Sarbar 1992). Free carbon dioxide present in water is chiefly begun from the respiration of aquatic biota, decomposition of organic matters and infiltration through the soil. Free $\mathrm{CO}_{2}$ is an important parameter of the buffer system and impacts the concentration of carbonates, bicarbonates, $\mathrm{pH}$ and total hardness in water. Higher level of free carbon dioxide during winter season may be attributed to increased decomposition rate under the river bed following slowdown of river water current. In the findings of Gupta et al. (1996) and Gupta and Mehrotra (1991), maximum value of free $\mathrm{CO}_{2}$ was found in the month of January and minimum in August.

\section{pH and alkalinity}

Acidification of stream water, which is one of the major problems of stream ecosystems worldwide, can result from anthropogenic stresses such as acid mine drainage (Herlihy et al. 1990) or the atmospheric deposition of nitric and sulfuric acids (Angelier 2003). However, naturally acidic streams can further be found in areas with considerable humic inputs (Allan 1995). $\mathrm{pH}$ has been recognized as a

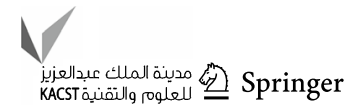


regulating factor in aquatic systems, and the biological components are severely affected at extremes of their $\mathrm{pH}$ tolerance. In aquatic ecosystems, photosynthesis and respiration often are the most important metabolic processes affecting $\mathrm{pH}$. Photosynthesis produces oxygen and raises $\mathrm{pH}$; aerobic respiration consumes oxygen and lowers $\mathrm{pH}$. Temperature regulates the rates of photosynthesis, community respiration, and other metabolic processes, and these rates are strongly influenced by inter-annual climate variation and also changes in climate over longer periods of time. Rates of photosynthesis and respiration in running waters also are influenced by hydrologic changes, including those associated with climate variation or water management (Cronin et al. 2007). Nitrogen and sulfur emissions are secondary products of industrial fuel combustion, and atmospheric deposition of these constituents can cause significant acidification of soil and stream water (Driscoll et al. 2001). Nitrate may also add to acidification and is made by natural sources such as coniferous forests (Thomsen and Friberg 2002) or from anthropogenic sources such as agricultural areas (EHMP 2004). As a result, streams that drain catchments dominated by coniferous forests or agricultural land uses tend to be acidic (Kawakami et al. 2001; Thomsen and Friberg 2002). The variation in $\mathrm{pH}$ is due to the presence or absence of free carbon dioxide and carbonate and periphytic algal density during various months (Lashari et al. 2009). The highest $\mathrm{pH}$ value was recorded during summer; this might be attributed to high photosynthetic rate due to the abundance of the algal population and increase in carbonate and due to the decomposition of organic matter (Kim et al. 2003; Kim and Kim 2006). The low pH values in autumn could be related to the overturn period and increase in rainfall both of which lead to reduction in $\mathrm{pH}$ value. The other factors responsible for variation in $\mathrm{pH}$ values include the combined effect of decrease in temperature and carbon dioxide concentration in water due to conversion of bicarbonate into carbonate (Sarbar 1992). Similar conclusion was made by Shaban (1980) and Toma (2000).

The weathering of parent material in the watershed is the key source of buffering substances found in the stream, which indicate that geology and climate expressively influence $\mathrm{pH}$. The carbonate system, which consists primarily of calcium- and magnesium-bearing carbonates and soluble nonresistant silicate minerals, is the key reason affecting the acid-neutralizing capacity (ANC) (Kang et al. 2001). If a sufficient amount of base cations, such as calcium, are present in the system, the hydrogen ions are removed from the solution, and the $\mathrm{pH}$ of the water remains stable (Kang et al. 2001). A number of research studies have indicated that ANC is strongly correlated to landscape variables and that statistical models can be used to make predictions in streams (Herlihy et al. 1998; Shirazi et al. 2001; Kellum 2003). Shirazi et al. (2001) investigated the relationship between catchment soil characteristics and water quality in the MidAtlantic region and found that the mean ANC increased as the soil particle size decreased. The geology (Shirazi et al. 2001; Kellum 2003; Cooper et al. 2004) and soil type (Shirazi et al. 2001) are related to ANC because the parent material in the catchment is a significant source of carbonates (Jenny 1941), while the climate, elevation (Kellum 2003) and aspect of the catchment affect the rate at which the parent material weathers. ANC tends to be lower in headwaters compared to larger streams that drain the watershed (Ward 1992). Increased levels of ANC have been associated with catchments containing agricultural and urban land uses (Johnson et al. 1997; Herlihy et al. 1998; Kellum 2003), while forested watersheds tend to yield lower ANC values (Herlihy et al. 1998; Cooper et al. 2004). Streams with high alkalinity from limestone dissolution are considered to be highly productive than streams draining more inert bedrocks such as granite massifs (Krueger and Waters 1983). The presence of limestone rocks results in higher $\mathrm{pH}$ (Ormerod and Gee 1990). Alkaline water promotes high primary productivity (Kumar and Prabhahar 2012). Alkaline nature of water was also reported in Greater Zab River, Iraq (Ali 2010). Alkalinity $\left(20-200 \mathrm{mg} \mathrm{L}^{-1}\right)$ is common in most of the freshwater ecosystems including ponds, lakes, streams and rivers (Hem 1985; Ishaq and Khan 2013). Natural water is mostly alkaline in nature due to the presence of carbonates in sufficient quantities (Todd 1995).

\section{Cations and anions}

The major cations including calcium $\left(\mathrm{Ca}^{2+}\right)$, magnesium $\left(\mathrm{Mg}^{2+}\right)$, sodium $\left(\mathrm{Na}^{+}\right)$and potassium $\left(\mathrm{K}^{+}\right)$exhibit slightly different seasonal patterns in their behavior and make up most of the cationic content of freshwater ecosystems. Four major anions, bicarbonate $\left(\mathrm{HCO}_{3}{ }^{-}\right)$, carbonate $\left(\mathrm{CO}_{3}{ }^{2-}\right)$, sulfate $\left(\mathrm{SO}_{4}^{-}\right)$and chloride $\left(\mathrm{Cl}^{-}\right)$, make up most of the ionic content of freshwater ecosystems. Other ions including phosphorus, nitrogen and iron make a minor contribution to total ions (Wetzel 2001). Concentrations of individual anions vary considerably on a spatial basis, owing to variability in natural and anthropogenic inputs (Allan 1995). Majority of the lotic systems across the different continents contain more than $50 \% \mathrm{HCO}_{3}{ }^{-}$and, from 10 to $30 \%\left(\mathrm{SO}_{4}{ }^{-}+\mathrm{Cl}\right)$, reflect the dominance of sedimentary rock weathering particularly carbonate minerals (Berner and Berner 1987).

In natural water bodies, calcium $\left(\mathrm{Ca}^{2+}\right)$ is known to decrease the noxiousness of many chemical compounds $\left(\mathrm{NO}_{2}\right)$ on fish and other aquatic life (William et al. 1986). $\mathrm{Ca}^{2+}$ occurs often in the form of calcium salts $\left(\mathrm{CaCl}_{2}\right.$ or $\left.\mathrm{CaCO}_{3}\right) \cdot \mathrm{Ca}^{2+}$ is removed by either ion exchange or calcite $\left(\mathrm{CaCO}_{3}\right)$ precipitation. Calcite precipitation occurs when $\mathrm{CO}_{2}$ content (in balance) is low, causing chemical reaction process to reverse the direction (Nikanorov and Brazhnikova 
2012). The magnesium ion $\left(\mathrm{Mg}^{2+}\right)$ occurs as a result of chemical weathering and dissolution of dolomite, marls and other rocks. The $\mathrm{Mg}$ ion is rarely dominant in natural waters. This is due to the fact that $\mathrm{Mg}$ has weak biological activity and the highest solubility. The dissolution of Mg-rich minerals is usually a slow process (Ramesh and Jagadeeswari 2012). The $\mathrm{Ca}: \mathrm{Mg}$ ratio reduces in waters undergoing a medium-to-high water mineralization. Erosion of rocks (limestone and dolomite) and minerals (calcite and magnesite) is the most common source of $\mathrm{Ca}$ and $\mathrm{Mg}$. Leaching of soil by erosion, pollution from sewage and industrial waste can also contribute to $\mathrm{Ca}$ and $\mathrm{Mg}$ (Nikanorov and Brazhnikova 2012). The concentration of $\mathrm{CO}_{3}{ }^{2-}$ ions is insignificant compared to $\mathrm{HCO}_{3}{ }^{-}$ions. Both $\mathrm{CO}_{3}{ }^{2-}$ and $\mathrm{HCO}_{3}{ }^{-}$ions typically occur in the form of carbonate system of chemical equilibrium, usually related to the alkalinity $(\mathrm{pH})$ and hardness of water which gives an unpleasant taste to water. $\mathrm{HCO}_{3}{ }^{-}$and $\mathrm{CO}_{3}{ }^{2-}$ ions are the key ions in waters having $\mathrm{pH}>8.2$. The sources of $\mathrm{CO}_{3}{ }^{2-}$ and $\mathrm{HCO}_{3}{ }^{-}$ions are the erosion of carbonate rocks (limestone, dolomite, magnesite), which results in precipitation of $\mathrm{CO}_{2}$ (Nikanorov and Brazhnikova 2012). Bouwer (1978) indicated that $\mathrm{HCO}_{3}{ }^{-}$is mainly produced due to the action of $\mathrm{CO}_{2}$ from the atmosphere and released from organic decomposition. Dissolution of carbonic acid $\left(\mathrm{H}_{2} \mathrm{CO}_{3}\right)$ is also the source of $\mathrm{HCO}_{3}{ }^{-}$ions (Ramesh and Jagadeeswari 2012). $\mathrm{HCO}_{3}{ }^{-}$ions are usually prevailing in waters with low mineralization, often in waters with moderate mineralization (Anonymous 2013). The high values of hardness recorded amid winter season in the Baldi stream may be ascribed to the increased mobilization of hardness causing components like calcium and magnesium to be discharged from the subsurface ground waters having higher hardness (USEPA 2000; Badrakh et al. 2008; Sharma et al. 2016). Higher values of hardness were also reported in Haraz River, Iran (Jafari et al. 2011). The concentration of calcium ranged from $68.33 \mathrm{mg} \mathrm{L}^{-1}$ (S1) to $60.35 \mathrm{mg} \mathrm{L}^{-1}$ (S3) in the Baldi stream (Sharma et al. 2016). As compared to calcium concentration, a low concentration of magnesium was observed in Baldi stream (Sharma et al. 2016).

Potassium minerals have a weak migratory ability (Nikanorov and Brazhnikova 2012) and are resistant to decomposition by weathering (Pradhan and Pirasteh 2011). Moreover, most salts of $\mathrm{Na}$ are not active in chemical reactions even if they are readily soluble in water (Pradhan and Pirasteh 2011). Weathering of Na-K-bearing minerals/rocks (halite, feldspar and montmorillonite), ion (cation) exchange process, pollution from industrial effluent and domestic sewage, and/or agricultural activities are responsible for the dominance of $\mathrm{Na}-\mathrm{K}$ in water bodies. Halite $(\mathrm{NaCl})$ dissolution can also be the source of $\mathrm{Na}$. The main source of $\mathrm{K}$ in the watershed would be weathering of potash silicate minerals and agrochemicals (potash fertilizers). The source of $\mathrm{Na}$ ion may be due to deposition of rock salts, weathering of rocks (limestone), and its displacement from absorbed complex of rocks and soils by $\mathrm{Ca}$ and $\mathrm{Mg}$.

Chloride ion typically exists in the form of chlorine salts $\left(\mathrm{NaCl}, \mathrm{CaCl}_{2}\right.$ and $\left.\mathrm{MgCl}_{2}\right)$ and is highly soluble in water. Their presence in water is generally related to leaching from minerals (gallite, sylvite, carnallite and bischofite), rocks (nephelines) and saline deposits. It also results in industrial and municipal wastes and irrigated agricultural activities (Anonymous 2013). The natural sources of $\mathrm{Cl}^{-}$ions include sedimentary rocks and other common evaporate minerals (chloride salts) (Pradhan and Pirasteh 2011; Ramesh and Jagadeeswari 2012).

Sulfur, an important constituent of natural waters, originates from natural sources including mineral weathering (Alewell et al. 1999), volcanoes, decomposition of organic matter and sea salt from the ocean surface (Kellogg et al. 1972; Nikanorov and Brazhnikova 2012; Herojeet et al. 2013). However, sulfur is also produced by industrial sources, such as mining, paper mills, textile mills and tanneries (Singleton 2000a, b). Atmospheric emissions of sulfur from the burning of fossil fuels result in bulk precipitation and dry deposition of $\mathrm{SO}_{4}{ }^{2-}$ (Alewell et al. 1999). Agricultural fertilizers have also been shown to produce elevated $\mathrm{SO}_{4}{ }^{2-}$ levels in stream water (Kellogg et al. 1972).

\section{Nutrients}

Dissolved inorganic phosphorus, inorganic nitrogen as nitrate and ammonia, silica and iron are generally regarded as critical nutrients to the aquatic ecosystem functioning (Dodds 2002; Allan and Castillo 2007). Nitrogen, phosphorus, silica and iron are the nutrients most often studied by aquatic ecologists (Dodds 2002). Nutrients in dissolved inorganic forms enter the streams from upstream, groundwater, surface runoff and atmospheric inputs (Allan 1995; Allan and Castillo 2007). Nitrogen and phosphorus are the major nutrients, and their sources and supplies vary considerably with geology, soil, climate and vegetation (Dodds 2006). Nitrogen and phosphorus concentrations are often elevated owing to the anthropogenic inputs (Carpenter et al. 1998). Significant anthropogenic inputs of nitrogen and phosphorus to streams include agricultural fertilizers, atmospheric deposition, nitrogen fixing crops and human and animal wastes (Boyer et al. 2002). Anthropogenic sources include municipal and industrial wastewaters, termed point source pollution, because it enters surface waters at a point, usually through a pipe; fertilizers and manure from farm fields referred to as nonpoint sources because of their diffuse entry into streams via surface and subsurface runoff (Edwards et al. 2000; Goller et al. 2006). Dissolved nutrients are incorporated into organic form by biological uptake and assimilation, moving through food web by consumption, and

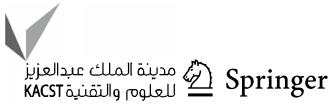


subsequently mineralized to inorganic form by excretion and decomposition of organic matter.

The principal dissolved form of silica is silicic acid, originating from the weathering of aluminosilicate minerals and from anthropogenic inputs, mainly sewage discharges (Allan 1995). Silica in rivers rarely is in short supply, and concentrations of silicon in rivers and streams remain remarkably constant over time (Wetzel 2001). The occurrence of iron in aquatic ecosystem is dependent on oxidation and reduction. Iron occurs as ferric and ferrous ions in oxic and anoxic habitats, and process is strongly influenced by microbiological activity. It also occurs as a metal pyrite $(\mathrm{FeS})$ in anoxic habitats and a flocculent precipitate $\left(\mathrm{Fe}(\mathrm{OH})_{3}\right)$ in oxic conditions (Hem 1985; Dodds and Welch 2000).

Odum (1956) concluded that polluted streams, which are, of course, greatly enriched by nutrients, are possibly the areas of highest primary production on the planet. It is pertinent to maintain here that running water, simply because it is running, is a richer habitat than still water. This has been pointed out long ago by Ruttner (1926), who stressed that current, by preventing the accumulation of a shell of depleted water round an organism, constantly presents fresh material to its surface to replace that used by metabolism. Phosphorus occurs primarily as phosphates in natural waters, which can be separated in inorganic and organic forms. Phosphate concentration depends on natural weathering of minerals in drainage basin, biological decomposition of organic matter and as runoff from human activities in urban and agricultural areas (Dodds et al. 1998; Sharpley 1995). Phosphorus levels are generally higher in areas draining sedimentary rock deposits (Dillon and Kirchner 1975). Anthropogenic sources include municipal sewage (point source pollution) and fertilizers and manure from farmlands (nonpoint sources) because of their diffuse entry into streams via surface and subsurface runoff (Edwards et al. 2000; Goller et al. 2006). Inorganic phosphorus, as orthophosphate $\left(\mathrm{PO}_{4}{ }^{3-}\right)$, is biologically accessible to primary producers that depend on phosphorus for production and has been established to be a significant nutrient limiting maximum biomass of these organisms in many inland systems (Allan 1995; Dodds and Welch 2000; Dodds 2002). Phosphorus concentration varies seasonally considerably owing to changes in hydrology, growing season and the changes in anthropogenic inputs (Allan and Castillo 2007). Phosphorus generated from plant breakdown and stored in the soil organic layer is an important input, entering streams by surface runoff and subsurface pathways (McDowell et al. 2001).

Sharpley and Syers (1979) from their study have concluded that the animal waste and fertilizers are the major source of nutrient enrichment to the streams from runoff events, subsurface flow and point sources such as farm ponds. The main sources of nitrate and phosphate in natural streams are rainfall and the land surface (Hynes 1970;
Schuetz et al. 2016). It is also known that drainage from agricultural land produces large amounts of nitrate and phosphate. Turner et al. (2003a, b) in their study on Widdybank Fell, Upper Teesdale National Nature Reserve, an upland area of northern England found occurrence of highest concentrations of organic $\mathrm{P}$ in 'pulses' during the spring. These pulses were attributed to have originated in the soil following drying and; rewetting cycles, and appeared to demonstrate hydrochemical connectivity between soils and streams. In Wisconsin, it was found that runoff constituted about $7.7 \mathrm{~kg}$ of nitrate nitrogen and $0.38 \mathrm{~kg}$ of phosphorus per hectare per year (Sawyer 1947). Similar figures have been given by Owen and Johnson (1966) for phosphate draining into streams in southern Ontario. Madler (1961) made an extensive study of phosphate in streams, and he found that it was soon eliminated from the water. Neel (1951) noted that the concentration of both nitrogen and phosphorus nutrients decreased as the water passed over riffles. Minckley (1963), while working on Doe Run, recorded that the water was exceptionally rich in nutrients from the limestone feeding spring source; however, the concentration decreased during periods of low flow. The observations in Volga show that the nitrate content of the water may fall to zero in the summer and rise to well over $1 \mathrm{mg} \mathrm{L}^{-1}$ in the winter when plants are not active (Shadin 1956). Exceptional areas of plant growth, such as the Sudd on the White Nile, act as traps for nutrients (Talling 1957). Nitrogen, phosphorus and silicon are most heavily utilized nutrients and are of primary importance. These inorganic material forms that are necessary for life are referred to as macronutrients (Allan 1995).

The dissolved inorganic forms of nitrogen are always in a dynamic state in aquatic ecosystems. Nitrogen occurs in a variety of inorganic and organic forms, and concentration of each form is biologically mediated depending on temperature profile of the environment (Wetzel 2001; Kayranli et al. 2010). The sources of these various forms of nitrogen include atmospheric diffusion, runoff and anthropogenic inputs from sewage discharge and agricultural fertilizers (Bernhardt et al. 2002; Juhair et al. 2011; Swaney et al. 2012). Ammoniacal nitrogen is one of the important bioavailable forms of nitrogen and is generally used preferentially over nitrate and nitrite by autotrophs, bacteria and fungi (Kemp and Dodds 2001; Bernot et al. 2006). Natural concentrations of $\mathrm{NO}_{3}$ in stream water are small compared to streams pretentious by anthropogenic inputs (Meybeck 1982), which are generally responsible for elevated $\mathrm{NO}_{3}$ levels in stream water (Chapin et al. 2002). Agricultural fertilizers may be flushed from fields during storm events and are a source of $\mathrm{NO}_{3}{ }^{-}$in stream water. Feed lots also act as agricultural point sources because animal manure contains $\mathrm{NO}_{3}$ (Sheets 1980; Ding et al. 2015). Inputs from urban areas, such as $\mathrm{NO}_{3}$-rich municipal waste water (Allan 1995) that comes from residential fertilizers, septic systems, 
and garbage dumps are important sources of nutrients in streams (Sheets 1980). Therefore, it is important to correlate $\mathrm{NO}_{3}{ }^{-}$with percent agriculture (Osborne and Wiley 1988; Herlihy et al. 1998; Kebede et al. 2014) and percent urban land use in the watershed (Herlihy et al. 1998; Arango and Tank 2008; Huang et al. 2014). $\mathrm{NO}_{3}{ }^{-}$has been found to exhibit higher concentrations under storm-flow conditions in certain rural catchments, suggesting diffuse (catchment) sources, possibly derived from agricultural runoff (Jarvie et al. 1997; Ding et al. 2015). Leira and Sabater (2005) recorded an increased concentration of nutrients downstream in many Catalan rivers, North Eastern Spain, which varied more spatially than did other major variables. Liera and Sabater (2005) believed that such variations result from extensive applications of chemical fertilizers in agricultural areas and diverse sewage inputs. Wakida and Lerner (2006) believed that there are nitrate sources, other than agricultural fertilizer additions, related to urban development that can increase nitrate concentrations in water. Xue et al. (2016) using isotopic and hydrochemical approaches recorded that domestic sewage and agricultural activities are the main sources of nitrate in the Weihe River watershed, China.

Silica is exclusively derived from the weathering of silicate rocks. Concentrations of silica, a micronutrient, thus vary considerably with underlying geology and also increase substantially with the increase in temperature (Wetzel 2001). Depletion of silica tends to occur more often in lakes and reservoirs than in running waters (Cambers and Ghina 2005). The occurrence of iron in aquatic ecosystems is primarily dependent on environmental conditions, especially oxidation and reduction. Flowing waters, fully aerated, should not contain more than a few micrograms of uncomplexed iron at equilibrium in the $\mathrm{pH}$ range of 6.0-8.5 (Chapman and Kimstach 1992; Dodds and Welch 2000; Dodds 2002).

\section{Land-use/land-cover change}

Human activities are responsible for a great extent in the modification of land use/land cover (LULC) worldwide, thereby affecting lotic systems and their watersheds (Schnaiberg et al. 2002). LULC in a watershed can influence the overall quality of stream ecosystems by directly altering hydrology, physicochemical conditions, and benthic habitat conditions, which, in turn, alters assemblage composition (Clements et al. 2000; Bledsoe and Watson 2001; Riis and Sand-Jensen 2001; Boyer et al. 2002; Schuetz et al. 2016). Hynes (1975) argued with a lasting impact that 'In every respect, the valley rules the stream.' Streams are progressively investigated from a landscape perspective, both as landscapes in their own right and as ecosystems that are being strongly influenced by their catchment characteristics at multiple scales (Allan et al. 1997; Townsend et al. 2003). Effect of land use on a stream ecosystem can vary depending on many factors, including riparian forest buffer quality, watershed size, reach location within its watershed, the presence of other pressures, and the scale on which land use is measured (Roy et al. 2003).

Ecologists have documented that rivers and streams are influenced by the land use/land cover through which they flow (Hynes 1975; Vannote et al. 1980; Schuetz et al. 2016). Land-use patterns in a watershed influence the delivery of nutrients, sediments and contaminants into receiving waters through surface flow, groundwater flow, organic inputs and atmospheric deposition (Jordan et al. 1997; Arango and Tank 2008; Huang et al. 2014). Streams are progressively investigated from a landscape perspective, both as landscapes in their own right and as ecosystems that are being strongly influenced by their catchment characteristics at multiple scales (Allan et al. 1997; Fausch et al. 2002; Townsend et al. 2003). Percentage of agricultural land use/land cover at catchment scale is a prime predictor for nitrogen and phosphorus (Hill 1981; Liu et al 2004; Johnson et al. 1997; Smart et al. 1998; Ferrier et al. 2001; Ahearn et al. 2005). Nevertheless, bare lands coverage is the key variable to predict nitrogen concentrations (Hunsaker and Levine 1995) that indicates a pronounced effect of weathering of bare rocks and gravels on nitrogen contents in the fluvial system (Holloway et al. 1998; Sliva and Williams 2001). Research has validated that changing land use/land cover may affect instream habitat and macroinvertebrate communities in number of ways. According to Quinn et al. (1997), the removal of streamside vegetation and subsequent increased solar radiation reaching the stream channel can elevate temperatures and alter thermal regimes that are critical to the life history and ecology of macroinvertebrates. Allan (2004) reported that the flow pathways and nutrient inputs are governed by integrated effects of land use. According to Allan et al. (1997), increase in the concentration of nitrogen and phosphorus in stream water is the direct result of the increase in agricultural and urban land use, while as a decrease in the concentrations of both the nutrients is because of the increase in forest land cover. Johnson et al. (1997) reported that land use within the riparian zone and throughout the catchment was equally effective in prediction of total nitrogen, nitrate, orthophosphate and alkalinity. Numerous studies have documented that the decline in water quality, habitat and biological assemblages as the extent of agricultural land increases within catchments (Wang et al. 1997; Ding et al. 2015). Majority of the studies have concluded that agricultural land use strongly influences stream water nitrogen (Arheimer and Liden 2000; Poor and McDonnell 2007; Kebede et al. 2014), phosphorus (Arheimer and Liden 2000), and sediments (Allan et al. 1997; Johnson et al. 1997; Schuetz et al. 2016).

Roth et al. (1996) found higher index of biotic integrity (IBI) scores in areas of higher forest and lower agriculture. 
Similarly, Wang et al. (2000) reported the IBI increase with the increase in forest cover than agricultural and urban land cover. The forest cover in the Vishav catchment is declining at a faster rate as a result of deforestation for the conversion to agricultural purposes and extraction of timber for construction purposes. According to Allan (2004), decline in forested land and increase in agriculture and urban lands frequently are predictors of a degraded state of the habitat and biota. Forest cover is an important aspect of good health (ecological conditions) of stream ecosystems as even modest riparian deforestation in highly forested catchments can result in degradation of stream habitat owing to sediment inputs (Sutherland et al. 2002).

\section{Urbanization}

Recent expansion of urban land areas all over the world has affected the chemistry and biology of streams in number of ways (Paul and Meyer 2001; Walsh et al. 2005a, b). With the increase in impervious surface cover (ISC), the infiltration of precipitation into soil decreases, resulting in earlier peak stream discharges and have short duration (Paul and Meyer 2001; Walsh et al. 2005a, b). Urbanization exerts profound effects on the landscape and associated aquatic systems, such as redirection of rainfall by impervious surfaces and increase in surface runoff (Mcmahon and Cuffney 2000), increase in sediment load, and decrease in sediment particle size (Chadwick et al. 2006; Brown et al. 2009). Urban land use also has adverse effects on the stream and water quality, especially when present in critical amounts and close to the stream channel (Wang et al. 2000, 2001). Major changes associated with increased urban land area include increases in the amounts of pollutants in runoff conveyance, increased water temperatures owing to the loss of riparian vegetation and warming surface runoff on exposed surfaces, and reduction in channel and habitat structure owing to sediment inputs, bank stabilization and restricted interaction between the river and its margin (Paul and Meyer 2001). From the documented research, the catchment analysis revealed that urban land contributed much lesser $(1.5 \%)$ to the total catchment area, suggesting that this area may not cause many changes to the natural functioning of the fluvial system. According to Paul and Meyers (2001), range of 10-20\% impervious area or urban land provides a threshold to the stream health conditions. Morley and Karr (2002) observed a strong decline in benthic IBI with increasing urban land cover. Several studies of urban ecosystems suggest that stream conditions respond nonlinearly to urbanization and that serious degradation takes place in the range of $15-25 \%$ urban land cover or urban land cover or impervious surface (Wang et al. 2000). Li et al. (2008) found a significant positive correlation between dissolved phosphorus and urban land area while working out the water quality in relation to land use and land cover in
Han River basin, China, which was consistent with previous reports (Osborne and Wiley 1988; Ferrier et al. 2001; Sliva and Williams 2001).

In comparison with rural streams, urban streams are characterized by elevated concentrations of solutes, such as nitrate, sulfate, chloride and base cations, even under baseflow situation (Wernick et al. 1998; Mcmahon and Cuffney 2000). Lewis et al. (2007) found that the concentration of most major anions and cations (nitrate, sulfate, chloride, sodium, potassium and calcium) was highest in urbanized headwaters, while examining the influence of headwater urbanization on the water chemistry, microbiology and fish communities of the Big Brushy Creek watershed, in the Piedmont of South Carolina, USA.

\section{Conclusion}

Our paper focused on the influence of local determinants including both natural and anthropogenic factors on stream water quality. Local determinants profoundly contribute to the spatiotemporal variation of stream water quality. Natural determinants related to geology, atmospheric deposition associated with precipitation, weathering process and anthropogenic inputs related to urban, industrial and agricultural activities were identified as potential factors to drive spatiotemporal variations in stream water quality. Anthropogenic activities and catchment characteristics drive spatial variability in stream water quality parameters. Indeed, understanding how this relationship changes over space and time will help policy makers and resource managers to target appropriate scales at watershed level for the quality conservation and management of stream waters.

Acknowledgements Authors are highly indebted to H.O.D Environmental Science for providing necessary facilities. This study was financially supported by University of Kashmir, Srinagar, 190006.

\section{Compliance with ethical standards}

Conflict of interest The authors declare that they have no conflict of interest.

Open Access This article is distributed under the terms of the Creative Commons Attribution 4.0 International License (http://creativeco mmons.org/licenses/by/4.0/), which permits unrestricted use, distribution, and reproduction in any medium, provided you give appropriate credit to the original author(s) and the source, provide a link to the Creative Commons license, and indicate if changes were made.

\section{References}

Ahearn DS, Sheibley RW, Dahlgren RA, Keller KE (2004) Temporal dynamics of stream water chemistry in the last free-flowing 
river draining the western Sierra Nevada, California. J Hydrol 295(1-4):47-63

Ahearn DS, Sheibley RS, Dahlgren RA, Anderson M, Jonson J, Tate KW (2005) Land use and land cover influence on water quality in the last free-flowing river draining the western Sierra Nevada, California. J Hydrol 313:234-247

Alewell C, Mitchell MJ, Likens GE, Krouse HR (1999) Sources of stream sulfate at the Hubbard Brook Experimental Forest: long-term analyses using stable isotopes. Biogeochemistry 44:281-299

Ali AL (2010) Seasonal variation in physico-chemical properties and zooplankton biomass in Greater Zab River, Iraq. Jordan J Biol Sci 3:115-120

Allan JD (1995) Stream ecology: structure and function of running waters. Chapman and Hall, London

Allan JD (2004) Landscapes and riverscapes: the influence of land use on stream ecosystems. Annu Rev Ecol Evol Syst 35(1):257-284

Allan JD, Castillo MM (2007) Stream ecology: structure and function of running waters, 2nd edn. Chapman and Hall, New York

Allan JD, Erickson DL, Fay J (1997) The influence of catchment land use on stream integrity across multiple spatial scales. Freshw Biol 37:149-161

Angelier E (2003) Ecology of streams and Rivers. Science Publishers, Inc., Enfield

Anonymous (2013) Groundwater quality. http://www.in.giv/dnr/water/ files/WFWR_web50-119.pdf. Accessed 18 June 2013

Arango CP, Tank JL (2008) Land use influences the spatiotemporal controls on nitrification and denitrification in headwater streams. J N Am Benthol Soc 27:90-107

Arheimer B, Liden R (2000) Nitrogen and phosphorus concentrations for agricultural catchments: influence of spatial and temporal variables. J Hydrol 227(1-4):140-159

Arismendi I, Safeeq M, Dunham JB, Johnson SL (2014) Can air temperature be used to project influences of climate change on stream temperature. Environ Res Lett 9(8). https://doi. org/10.1088/1748-9326/9/8/084015

Arthington AH, Naiman RJ, McClain ME, Nilsson C (2010) Preserving the biodiversity and ecological services of rivers: new challenges and research opportunities. Freshw Biol 55:1-16

Badrakh A, Chultemdorji T, Tserendorj T, Vanya D, Dalaijamts C, Hagan R, Govind S, Shinee E (2008) A study of the quality and hygienic conditions of spring water in Mongolia. J Water Health 6:141-148

Beechie T, Imaki H, Greene J, Wade A, Wu H, Pess G (2013) Restoring salmon habitat for a changing climate. River Res Appl 29:939-960

Berman CH, Poole GC (2001) An ecological perspective on in-stream temperature: natural heat dynamics and mechanisms of humancaused thermal degradation. Environ Manag 27(6):787-802

Berner EK, Berner RA (1987) The global water cycle. Prentice-Hall, Englewood Cliffs

Bernhardt ES, Hall RO, Likens GE (2002) Whole-system estimates of nitrification and nitrate uptake in streams of the Hubbard Brook Experimental Forest. Ecosystems 5:419-430

Bernot MJ, Tank JL, Royer TV, David MB (2006) Nutrient uptake in streams draining agricultural catchments of the Midwestern United States. Freshw Biol 51:499-509

Biggs BJF, Duncan MJ, Jowett IG, Quinn JM, Hickey CW, DaviesColley RJ, Close ME (1990) Ecological characterisation, classification and modelling of New Zealand rivers: an introduction and synthesis. N Z J Mar Freshw Res 24:277-304

Bledsoe BP, Watson CC (2001) Effects of urbanization of channel instability. J Am Water Resour Assoc 37:255-270

Bouwer H (1978) Groundwater hydrology. McGraw-Hill, New York
Boyer EW, Goodale CL, Jaworski NA, Howarth RW (2002) Anthropogenic nitrogen sources and relationships to riverine nitrogen export in the northeastern USA. Biogeochemistry 57(58):137-169

Brown LR, Cuffney T, Coles JF, Bell AH, May JT, Fitzpatrick F, Mcmahon G, Steuer J (2009) Urban streams across the US: lessons learned from studies in 9 metropolitan areas. J N Am Benthol Soc 28:1051-1069

Brown LE, Cooper L, Holden J, Ramchunder SJ (2010) 'A comparison of stream water temperature regimes from open and afforested moorland, Yorkshire Dales, northern England. Hydrol Process 24:3206-3218

Burns DA, Murdoch PS, Lawrence GB (1998) Effect of groundwater springs onnitrate concentrations during summer in Catskill Mountain streams. Water Resour Res 34(8):1987-1996

Butcher RW (1940) Studies in the ecology of rivers: IV. Observations on the growth and distribution of the sessile algae in the River Hull, Yorkshire. J Ecol 28(1):210-223

Butcher RW, Longwell J, Pentelow FTK (1937) Survey of the River Tees. Part 3. The non-tidal reaches-chemical and biological. Technical Paper Water Pollution Research London, No. 6

Caissie D (2006) River discharge and channel width relationships for New Brunswick Rivers. Canadian Technical Report of Fisheries and Aquatic Sciences, pp 26-37

Cambers G, Ghina F (2005) Water Quality, an Introduction to Sandwatch. An Educational Tool for Sustainable Development. United Nations Educational, Scientific and Cultural Organization (UNESCO): Paris, France. pp. 25-31 http://www.unesco.org/csi

Carpenter SR, Caraco NF, Correll DL, Howarth RW, Sharpley AN, Smith VH (1998) Nonpoint pollution of surface waters with phosphorus and nitrogen. J Appl Ecol 8:559-568

Caruso BS (2002) Temporal and spatial patterns of extreme low flows and effects on stream ecosystems in Otago, New Zealand. J Hydrol 257:115-133

Chadwick MA, Dobberfuhl DR, Benke AC, Huryn AD, Suberkropp K, Thiele JE (2006) Urbanization affects stream ecosystem function by altering hydrology, chemistry, and biotic richness. Ecol Appl 16:1796-1807

Chang H (2002) Spatial and temporal variations of water quality in the river and its tributaries, Seoul, Korea, 1993-2002. Water Air Soil Pollut 161:267-284

Chapin FS, Matson PA, Mooney HA (2002) Principles of terrestrial ecosystem ecology. Springer, New York

Chapman D, Kimstach V (1992) The selection of water quality variables. An introduction to water quality. In: Chapman D (ed) Water quality assessments: a guide to the use of biota, sediments and water in environmental monitoring. Chapman and Hall Ltd., London

Clements WH, Carlisle DM, Lazorchak JM, Johnson PC (2000) Heavy metals structure benthic communities in Colorado mountain streams. Ecol Appl 10:626-638

Clenaghan C, O'Halloran J, Giller PS, Roche N (1998) Longitudinal and temporal variation in the hydrochemistry of streams in an Irish conifer afforested catchment. Hydrobiologia 389:63-71

Collins R, Jenkins A (1996) The impact of agricultural land use on stream chemistry in the middle hills of the Himalayas, Nepal. J Hydrol 185:137-150

Cooper DM, Helliwell RC, Coull MC (2004) Predicting acid neutralising capacity from landscape classification: application to Galloway, South West Scotland. Hydrol Process 18:455-471

Costello MJ, McCarthy TK, O'Farrell MM (1984) The stoneflies (Plecoptera) of the Corrib catchment area, Ireland. Ann Limnol 20(1-2):25-34

Crisp DT, Howson G (1982) Effect of air temperature upon mean water temperature in streams in the North Pennines and English Lake District. Freshw Biol 12:359-367

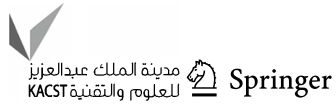


Cronin G, McCutchan JH, Pitlick J, Lewis WM (2007) Use of Shields stress to reconstruct and forecast changes in river metabolism. Freshw Biol 52:1587-1601

Cunningham MA, Menking KA, Gillikin DP, Batur P (2010) Influence of open space on water quality in an urban stream. Phys Geogr 31(4):336-356. https://doi.org/10.2747/0272-3646.31.4.336

Danehy RJ, Colson CG, Parrett KB, Duke SD (2005) Patterns and sources of thermal heterogeneity in Small Mountain streams within a forested setting. For Ecol Manag 208:287-302

Dauer DM, Ranasinghe JA, Weisberg SB (2000) Relationships between benthic community condition, water quality, sediment quality, nutrient loads, and land use patterns in Chesapeake Bay. Estuaries 23(1):80-96

Davies B, Valente MB, Hall A (2005) The Zambezi Rivers in Mozambique: the physicochemical status of the middle and lower Zambezi prior to the closure of the Cobora Bassa Dam. Freshw Biol 7:187-189

Dillon PJ, Kirchner WB (1975) The effects of geology and land use on the export of phosphorus from watersheds. Water Res 9:135-148

Ding J, Yuan Jiang Y, Fu L, Liu Q, Peng Q, Kang M (2015) Impacts of land use on surface water quality in a subtropical River Basin: a case study of the Dongjiang River Basin, Southeastern China. Water 7:4427-4445

Dodds WK (2006) Eutrophication and Trophic state in Rivers and Streams. Limnol Oceanogr 1(2):671-680. https://doi. org/10.4319/lo.2006.51.1.part2.0671

Dodds WK (2002) Freshwater ecology: concepts and environmental applications. Academic Press, San Diego

Dodds WK, Welch EB (2000) Establishing nutrient criteria in streams. J N Am Benthol Soc 19:186-196

Dodds WK, Jones JR, Welch EB (1998) Suggested classification of stream trophic state: distributions of temperate stream types by chlorophyll, total nitrogen, and phosphorus. Water Res 32:1455-1462

Dorris T, Copeland BJ, Lauer GJ (1963) Limnology of the middle Mississippi River. IV. Physical and chemical limnology of river and chute. Limnol Oceanogr 8:79-88

Driscoll CT, Lawrence GB, Bulger AJ, Butler TJ, Cronan CS, Eagar C, Lambert KF, Likens GE, Stoddard JL, Weathers KC (2001) Weathers, acidic deposition in the northeastern United States: sources and inputs, ecosystem effects, and management strategies. Bioscience 51:180-198

Dynesius M, Nilsson C (1994) Fragmentation and flow regulation of river systems in the northern third of the world. Science 202:629-631

Ecosystem Health and Monitoring Program (EHMP) (2004) Ecosystem Health and Monitoring Program 2002-2003 annual technical report. Ecosystem health and monitoring program, Morton Bay Waterways and Catchments Partnership Brisbane, Australia

Edington JM (1966) Some observations on stream temperature. Oikos $15: 265-273$

Edwards AC, Twist H, Codd GA (2000) Assessing the impact of terrestrially derived phosphorus on flowing water systems. J Environ Qual 29:117-124

Elwood JW, Newbold JD, Trimble AF, Stark RW (1981) The limiting role of phosphorus in a woodland stream ecosystem: Effects $\mathrm{P}: \mathrm{N}$ enrichment on leaf decomposition and primary producers. Ecology 62(1):146-158

Fausch KD, Torgersen CE, Baxter CV, Li HW (2002) Landscapes to riverscapes: abridging the gap between research and conservation of stream fishes. Bioscience 52:483-498

Ferrier RC, Edwards AC, Hirst D, Littlewood IG, Watts CD, Morris $\mathrm{R}$ (2001) Water quality of Scottish rivers: spatial and temporal trends. Sci Total Environ 265:327-342
Fisher SG, Likens GE (1973) Energy flow in Bear Brook, New Hampshire: An integrative approach to stream ecosystem metabolism. Ecol Monogr 43(4). https://doi.org/10.2307/1942301

Fraser BG, Williams DD (1997) Accuracy and precision in sampling hyporheic fauna. Can J Fish Aquat Sci 54:1135-1141

Garner G, Malcolm IA, Sadler JP, Hannah DM (2014a) What causes cooling water temperature gradients in a forested stream reach? Hydrol Earth Syst Sci 18:5361-5376

Garner G, Malcolm IA, Sadler JP, Millar CP, Hannah DM (2014b) Inter-annual variability in the effects of riparian woodland on micro-climate, energy exchanges and water temperature of an upland Scottish stream. Hydrol Process. https://doi.org/10.1002/ hyp. 10223

Garnier J, Mouchel JM (2013) Man and river systems: the functioning of river systems at the Basin Scale. Springer, Dordrecht. https:// doi.org/10.1007/978-94-017-2163-9

Gessner F (1961) Der Sauerstoffhaushalt des Amazonas. Internationale Revue der gesamten Hydrobiologie and Hydrographie 46:542-561

Goller R, Wilcke W, Fleischbein K, Valarezo C, Zech W (2006) Dissolved nitrogen, phosphorus and sulfur forms in the ecosystem fluxes of a montane forest in Ecuador. Biogeochemistry 77:57-89

Golterman HL (1975) Chemistry. In: Whitton BA (ed) River ecology. University of California Press, Berkeley, pp 39-80

Grantham TE, Merenlender AM, Resh VH (2010) Climatic influences and anthropogenic stressors: an integrated framework for streamflow management in Mediterranean-climate California, USA. Freshw Biol 55:188-204. https://doi.org/10.111 1/j.1365-2427.2009.02379.x

Gray J (2004) Conductivity analyzer and their application. In: Lehi RD (ed) Environmental instrumentation and analysis. Wiley Handbook, New York, pp 491-510

Gregory SV, Swanson FJ, Mckee WA, Cummins KW (1991) An ecosystem perspective of riparian zones. Bioscience 41:540-551

Gupta AK, Mehrotra RS (1991) Ecological studies on water moulds of Kurukshetra. Curr Trends Limnol 1:47-64

Gupta AK, Sharma M, Gorai AC, Pandey PN (1996) Impacts of coal mining effluents on the physic-chemical characteristics of Raja Tank, Jaria (Dhanbad). J Freshw Biol 8(2):63-73

Hall WA (1955) Theoretical aspects of water spreading. Am Soc Agric Biol Eng 36(6):394-399

Hannah DM, Garner G (2015) River water temperature in the United Kingdom: changes over the 20th century and possible changes over the 21st century. Prog Phys Geogr 39(1):68-92

Harrison AD, Elsworth JF (1958) Hydrobiological studies of the Great Berg River; Part 1. General description of chemical studies and main features of the flora and fauna. Trans R Soc S Afr 35(3): $125-226$

Hem JD (1985) Study and interpretation of the chemical characteristics of natural water: U.S Geological Survey. Water-Supply Paper, pp 2254-2263

Herlihy AT, Kaufmann PR, Mitch ME (1990) Regional estimates of acid mine drainage impact on streams in the Mid-Atlantic and southeastern United States. Water Air Soil Pollut 50:91-107

Herlihy A, Stoddard JL, Johnson CB (1998) The relationship between stream chemistry and watershed land cover data in the MidAtlantic region, USA. Water Air Soil Pollut 20:31-39

Herojeet K, Rishi MS, Sidhu N (2013) Hydrochemical characterization, classification and evaluation of groundwater regime in Sirsa Watershed, Nalagarh Valley, Himachal Pradesh, India. Civ Environ Res 3(7):47-57

Hill AR (1981) Stream phosphorus exports from watersheds with contrasting land uses in southern Ontario. Water Resour Bull $17: 627-634$

Hill WR, Ryon MG, Schilling EM (1995) Light limitation in a stream ecosystem: responses by primary producers and consumers. 
Ecology (ESA) 76(4):1297-1309. https://doi.org/10.2307/19409 36

Holloway JM, Dahlgren A, Hansen B, Casey WH (1998) Contribution of bedrock nitrogen to high nitrate concentrations in stream water. Nature 395:785-788

Hornbach DJ, Beckel R, Hustad EN, McAdam DP, Roen IM, Wareham AJ (2015) The influence of riparian vegetation and season on stream metabolism of Valley Creek, Minnesota. J Freshw Ecol 30(4):569-588

Hornbeck JW, Bailey SW, Buso DC, Shanley JB (1997) Stream water chemistry and nutrient budgets for forested watersheds in New England: variability and management implications. For Ecol Manag 93:73-89

Hornung M, Le-Grice S, Brown N, Norris D (1990) The role of geology and soils in controlling surface water acidity in Wales. In: Edwards RW, Gee AS, Stoner JH (eds) Acid waters in Wales. Kluwer Academic Publishers, Dordrecht, pp 55-66

Huang J, Huang Y, Zhang Z (2014) Coupled effects of natural and anthropogenic controls on seasonal and spatial variations of river water quality during baseflow in a coastal watershed of Southeast China. PLoS ONE 9(3):15-28

Hunsaker CT, Levine DA (1995) Hierarchical approaches to the study of water quality in rivers. BioScience 45:193-203

Hynes HBN (1960) The biology of polluted waters. Liverpool Univ. Press, Liverpool, p 202

Hynes HBN (1970) The ecology of running waters. Liverpool University Press, Liverpool

Hynes HBN (1975) The stream and its valley. Verhandlungen der Internationalen Vereinigung fur theoretische und angewandte Limnologie 19:1-15

Imholt C, Soulsby C, Malcolm IA, Gibbins CN (2012) Influence of contrasting riparian forest cover on stream temperature dynamics in salmonid spawning and nursery streams. Ecohydrology 6:380-392

Ishaq F, Khan A (2013) Aquatic biodiversity as an ecological indicator for water quality criteria of river Yamuna in Doon Valley, Uttarakhand, India. World J Fish Mar Sci 5:322-334

Jafari N, Nabavi SM, Akhavan M (2011) Ecological investigation of zooplankton abundance in the river Haraz Northeast Iran: impact of environmental variables. Arch Biol Sci Belgrade 63:785-798

Jarvie HP, Neal C, Leach DV, Ryland GP, House WA, Robson AJ (1997) Major ion concentrations and the inorganic carbon chemistry of the Humber Rivers. Sci Total Environ 194(195):285-302

Jarvie HP, Whitton BA, Neal C (1998) Nitrogen and phosphorus in east coast British Rivers: speciation, sources and biological significance. Sci Total Environ 210(211):79-109

Jenny H (1941) Factors of soil formation. McGraw-Hill, New York

Johnson LB, Richards C, Host GE, Arthur JW (1997) Landscape influences on water chemistry in Midwestern stream ecosystems. Freshw Biol 37:193-208

Jones JB Jr, Mulholland PJ (1998) Methane input and evasion in a hardwood forest stream: effects of subsurface flow from shallow and deep pathways. Limnol Oceanogr 42:1243-1250

Jordan TE, Correll DL, Weller DE (1997) Nonpoint source discharges of nutrients from piedmont watersheds of Chesapeake Bay. J Am Water Resour Assoc 33:631-643

Juhair H, Zain SM, Yousuf MK, Hanidza TIT, Armi ASM, Toriman ME, Mokhtar M (2011) Spatial water quality assessment of Langat River Basin (Malaysia) using environmental techniques. Environ Monit Assess 173:625-641

Kamler E (1965) Thermal conditions in mountain waters and their influence on the distribution of Plecoptera and Ephemeroptera larvae. Ekologia Polska 20:1-38

Kang JK, Song Y, Moon JW, Moon HS (2001) Water quality impact of mining in the Wolmyoung area of Korea, and its short-term changes. Water. Air Soil Pollut 129:349-367
Kawakami T, Honoki H, Yasuda H (2001) Acidification of a small stream on Kureha Hill caused by nitrate leached from a forested watershed. Water Air Soil Pollut 130:1097-1102

Kayranli B, Scholz M, Mustafa A, Hofmann O, Harrington R (2010) Performance evaluation of integrated constructed wetlands treating domestic wastewater. Water Air Soil Pollut 210(1-4):435-451

Kebede W, Tefera M, Habitamu T, Alemayehu T (2014) Impact of land cover change on water quality and stream flow in lake Hawassa watershed of Ethiopia. Agric Sci 5:647-659

Kellogg WW, Cadle RD, Allen ER, Lazrus AL, Martell EA (1972) The sulfur cycle. Science 175:587-596

Kellum B (2003) Analysis and modeling of acid neutralizing capacity in the Mid-Atlantic Highlands area. M.Sc. Thesis, Colorado State University, $69 \mathrm{pp}$

Kemp MJ, Dodds WK (2001) Spatial and temporal patterns of nitrogen concentrations in pristine and agriculturally- influenced prairie streams. Biogeochemistry 53:125-141

Kiernan JD, Moyle PB (2012) Flows, droughts, and aliens: factors affecting the fish assemblage in a Sierra Nevada, California, stream. Ecol Appl 22(4):1146-1161

Kim JY, An KG (2015) Integrated ecological river health assessments, based on water chemistry, physical habitat quality and biological integrity. Water 7:6378-6403

Kim SJ, Kim J (2006) How to evaluate the DOC and POC discharge from forest 15 ecosystem during monsoon? USA PUB Workshop, CUASHI

Kim SJ, Ohte N, Kawasaki M, Katsuyama M, Tokuchi N, Hobara S (2003) Interactive responses of dissolved sulfate and nitrate to disturbance associated with pine wilt disease in a temperate forest. Soil Sci Plant Nutr 49(13):539-550

Kondolf GM (1997) Hungry water: effects of dams and gravel mining on river channels. Environ Manag 21:533-551

Krueger CC, Waters TF (1983) Annual production of macroinvertebrates in three streams of different water quality. Ecology 64(4):840-850

Kumar MP, Prabhahar C (2012) Physico-chemical parameters of river water: a review. Int J Pharm Biol Arch 3:1304-1312

Laar C, Akiti TT, Brimah AK, Fianko JR, Osae S, Osei J (2011a) Hydrochemistry and isotopic composition of the Sakumo Ramsar Site Res. J Environ Earth Sci 3(2):146-152

Laar C, Fianko JR, Akiti TT, Osae S, Brimah AK (2011b) Determination of heavy metals in the black-chin tilapia from the Sakumo Lagoon, Ghana. Res J Environ Earth Sci 3:8-13

Lashari KH, Korai AL, Sahato GA, Kazi TG (2009) Limnological studies of Keenjhar Lake, District, Thatta, Sindh, Pakistan. Pak J Anal Environ Chem 10(1-2):39-47

Leira M, Sabater S (2005) Diatom assemblages distribution in Catalan rivers, NE Spain, in relation to chemical and physiographical factors. Water Res 39:73-82

Lewis GP, Mitchell JD, Andersen BC, Haney DC, Liao MK, Sargent KA (2007) Urban influences on stream chemistry and biology in the Big Brushy Creek watershed, South Carolina. Water Air Soil Pollut 182:303-323

Li S, Xu Z, Cheng X, Zhang Q (2008) Dissolved trace elements and heavy metals in the Danjiangkou Reservoir, China. Environ Geol. https://doi.org/10.1007/s00254-007-1047-5

Likens GE, Bormann FH, Pierce RS, Eaton JS, Johnson NM (1977) Biogeochemistry of a forested ecosystem. Springer, New York

Liu Y, Chen JN, Mol APJ (2004) Evaluation of phosphorus flows in the Dianchi Watershed, southwest of China. Popul Environ 25(6):637-656

Livingstone DA (1963) Chemical composition of rivers and lakes. Professional Paper U. S. Geological Survey, 440-G 
Lovett GM, Weathers KC, Sobczak W (2000) Nitrogen saturation and retention in forested watersheds of the Catskill Mountains, New York. Ecol Appl 10:73-84

Lusardi RA, Bogan MT, Moyle PB, Dahlgren RA (2016) Environment shapes invertebrate assemblage structure differences between volcanic spring fed and runoff rivers in northern California. Freshw Sci 35(3):1010-1022. https://doi. org/10.1086/687114

Macan TT (1958) The temperature of a small stony stream. Hydrobiologia 12:89-106

Macdonald JS, MacIsaac EA, Herunter H (2003) The effect of variableretention riparian buffer zones on water temperatures in small headwater streams in sub-boreal forest ecosystems of British Columbia. Can J For Res 33:1371-1382

Madler K (1961) Utersuchungenijber den Phosphorgehalt van Bachen. Int Rev Hydrobiol 46:75-83

Malcolm IA, Soulsby C, Hannah DM, Bacon PJ, Youngson AF, Tetzlaff D (2008) The influence of riparian woodland on stream temperatures: implications for the performance of juvenile salmonids. Hydrol Process 22(7):968-979. https://doi.org/10.1002/hyp.6996

Matthews WJ, Zimmerman EG (1990) Potential effects of global warming on native fishes of the southern Great Plains and the Southwest. Fisheries 15:26-31

McDowell R, Sharpley A, Folmar G (2001) Phosphorus export from an agricultural watershed: linking source and transport mechanisms. J Environ Qual 30:1587-1595

McMahon G, Cuffney TF (2000) Quantifying urban intensity in drainage basins for assessing stream ecological conditions. J Am Water Res Assoc 36(6):1247-1261. https://doi. org/10.1111/j.1752/1688.2000.tb05724.x

Meier W, Bonjour C, Wuest A (2003) Modeling the effect of water diversion on the temperature of mountain streams. J Environ Eng ASCE 129:755-764

Meybeck M (1982) Carbon, nitrogen, and phosphorus transport by world rivers. Am J Sci 282:401-450

Meyer JL, Tate CM, Edward RT, Crocker MT (1988) The trophic significance of dissolved organic carbon in streams. In: Swank WT, Crossley DA Jr (eds) Forest hydrology and ecology at Coweeia. Springer, New York, pp 269-278

Minckley WL (1963) The ecology of a spring stream, Doe Run, Meade County, Kentucky. Wildl Monogr 11:1-124

Moore RD, Spittlehouse DL, Story A (2005) Riparian microclimate and stream temperature response to forest harvesting: a review. J Am Water Resour Assoc 41(4):813-834. https://doi. org/10.1111/j.1752-1688.2005.tb03772.x

Morley SA, Karr JR (2002) Assessing and restoring the health of urban streams in the Puget Sound Basin. Conserv Biol 16:1498-1509

Mulholland PJ (2003) Large scale patterns in DOC concentration, flux, and sources. In: Findlay S, Sinsabaugh R (eds) Aquatic ecosystems: interactivity of dissolved organic matter. Elsevier Science, Amsterdam, pp 139-159

Naiman RJ, Elliott SR, Helfield JM, O'Keefe TC (2000) Biophysical interactions and the structure and dynamics of riverine ecosystems: the importance of biotic feedbacks. Hydrobiologia 410:79-86

Nakagawa Y, Iwatsubo G (2000) Water chemistry in a number of mountainous streams of east Asian. J Hydrol 240:118-130

Nakamura Y (1989) A method for dynamic characteristics estimation of subsurface using microtremor on the ground surface. Q Rep Rail Tech Res Inst 30:25-30

Needham PR, Jones AC (1959) Flow, temperature, solar radiation and icein relation to activities of fishes in Sagehen Creek, California. Ecology 40:465-474

Neel JK (1951) Interrelations of certain physical and chemical features in a headwater limestone stream. Ecology 32:368-391
Nikanorov AM, Brazhnikova LV (2012) Water chemical composition of rivers, lakes and wetlands. Types Prop Water 2:42-80

Odum HT (1956) Primary production in flowing waters. Limnol Oceanogr 1:102-117

Olden JD, Naiman RJ (2010) Incorporating thermal regimes into environmental flows assessments: modifying dam operations to restore freshwater ecosystem integrity. Freshw Biol 55:86-107

Olson JR (2012) The influence of geology and other environmental factors on stream water chemistry and benthic invertebrate assemblages. All Graduate Theses and Dissertations

Ormerod SJ, Gee AS (1990) Chemical and ecological evidence on the acidification of Welsh lakes and rivers. In: Edwards RW, Gee AS, Stoner JH (eds) Acid waters in Wales. Kluwer Academic Publishers, Dordrecht, pp 11-25

Osborne LL, Wiley MJ (1988) Empirical relationships between landuse cover and stream water-quality in an agricultural watershed. J Environ Manag 26:9-27

Owen GE, Johnson MG (1966) Significance of some factors affecting yields of phosphorus from several Lake Ontario watersheds. Pub.15, Great Lakes Res. Division, University of Michigan, pp 400-410

Owens M, Edwards RW (1964) A chemical survey of some English rivers. Soc Water Treat Exam Proc 13:134-144

Parfitt D, Buer K (1980) Upper Sacramento River spawning gravel study. California Department of Water Resources, Northern Division, Red Bluff

Paul MJ, Meyer JL (2001) Streams in the urban landscape. Annu Rev Ecol Syst 32:333-365

Pejman AH, Bidhendi GRN, Karbassi AR, Mehrdadi N, Esmaeili MB (2009) Evaluation of spatial and seasonal variations in surface water quality using multivariate statistical techniques. Int J Environ Sci Technol 6:467-476

Platts WS (1979) Relationships among stream order, fish populations, and aquatic geomorphology in an Idaho river drainage. Fisheries 4:5-9

Poff NL, Ward JV (1989) Implications of streamflow variability and predictability for lotic community structure: a regional analysis of streamflow patterns. Can J Fish Aquat Sci 46:1805-1818

Poff NL, Allan JD, Bain MB, Karr JR, Prestegaard KL, Richter BD, Sparks RE, Stromberg JC (1997) The natural flow regime: a paradigm for river conservation and restoration. Bioscience 47:769-784

Poor CJ, McDonnell JJ (2007) The effects of land use on stream nitrate dynamics. J Hydrol 332:54-68

Pradhan B, Pirasteh S (2011) Hydro-chemical analysis of the ground water of the basaltic catchments: upper Bhatsai region, Maharastra. Open Hydrol J 5:51-57

Quinn JM, Cooper AB, Davies-Colley RJ, Rutherford JC, Williamson RB (1997) Land use effects on habitat, water quality, periphyton, and benthic invertebrates in Waikato, New Zealand, hill-country streams. N Z J Mar Freshwat Res 31:579-597

Ramesh K, Jagadeeswari BP (2012) Hydrochemical characteristics of groundwater for domestic and irrigation purposes in Periyakulam taluk of Theni district, Tamil Nadu. Int Res J Environ Sci $1(1): 19-27$

Ramírez A, Rosas KG, Lugo AE, Ramos-González OM (2014) Spatiotemporal variation in stream water chemistry in a tropical urban watershed. Ecol Soc 19:11

Rani N, Sinha RK, Prasad K, Kedia DK (2011) Assessment of temporal variation in water quality of some important rivers in middle Gangetic plains, India. Environ Monit Assess 174(1-4): 401-415

Ravindra K, Ameena M, Monika R, Kaushik A (2003) Seasonal variations in physicochemical characteristics of river Yamuna in Haryana and its ecological best designated use. J Environ Monit $5: 419-426$ 
Rebsdorf A, Thyssen N, Erlandsen M (1991) Regional and temporal variation in $\mathrm{pH}$, alkalinity and carbon dioxide in Danish streams, related to soil type and land use. Freshw Biol 25:419-435

Resh VH, Brown AV, Covich AP, Gurtz ME, Li HW, Minshall GW, Reice SR, Sheldon AL, Wallace JB, Wissmar RC (1988) The role of disturbance in stream ecology. J N Am Benthol Soc 7(4):433-455

Rheinheimer DE, Viers JH (2014) Combined effects of reservoir operations and climate warming on the flow regime of hydropower bypass reaches of California's Sierra Nevada. River Res Appl 31(3):269-279

Riis T, Sand-Jensen K (2001) Historical changes in species composition and richness accompanying perturbation and eutrophication of Danish lowland streams over 100 years. Freshw Biol 46(2):269-280

Roth NE, Allan JD, Erickson DE (1996) Landscape influences on stream biotic integrity assessed at multiple spatial scales. Landsc Ecol 11:141-156

Roth TR, Westhoff MC, Huwald H, Huff JA, Rubin JF, Barrenetxea G, Vetterli M, Parriaux A, Selker JS, Parlange MB (2010) Stream temperature response to three riparian vegetation scenarios by use of a distributed temperature validated model. Environ Sci Technol 44:2072-2078

Roy AH, Rosemond AD, Paul MJ, Leigh DS, Wallace JB (2003) Stream macroinvertebrate response to catchment urbanization (Georgia, USA). Freshw Biol 48:329-346

Rutherford JC, Nicholas A, Peter M, Davies M, Bunn SE (2004) Effects of patchy shade on stream water temperature: how quickly do small streams heat and cool? Mar Freshw Res 55:737-748

Ruttner F (1926) Bermerkungentiber den Sauerstoffgehalt der Gewasser und dessenrespiratorischen Wert. Naturwissenschaften 14:1237-1239

Sabater S, Elosegi A (2013) River conservation: challenges and opportunities. Fundacion BBVA. ISBN: 978-84-92937-47-9

Salmiati S, Arman NZ, Salim MR (2017) Integrated approaches in water quality monitoring for river health assessment: scenario of Malaysian River. Water Qual. https://doi.org/10.5772/65703

Sarbar MA (1992) Carbon dioxide and weak acid content of Wasia Water. In: Proceedings of the International Conference on Chemistry in Industry, Bahrain

Sawyer CN (1947) Fertilization of lakes by agricultural and urban drainage. J N Engl Waterworks Assoc 61(2):109-127

Schmassmann HV (1951) Unter- suchungen tiber den Stoffhaushalt fliessender Gewasser. Schweiz Zeit Hydrol 13:300-335

Schnaiberg J, Riera J, Turner MG, Voss PR (2002) Explaining human settlement patterns in a recreational lake district: Vilas County, Wisconsin, USA. Environ Manag 30:24-34

Schuetz T, Gascuel-Odoux C, Durand P, Weiler M (2016) Nitrate sinks and sources as controls of spatio-temporal water quality dynamics in an agricultural headwater catchment. Hydrol Earth Syst Sci 20:843-857

Schultz AM, Begemann MH, Schmidt DA, Weathers KC (1993) Longitudinal trends in $\mathrm{pH}$ and aluminum chemistry of the Coxing Kill, Ulster County, New York. Water Air Soil Pollut 69:113-125

Shaban AAG (1980) An ecological study on phytoplankton in Dokan Lake. M.Sc.Thesis, University of Salahaddin, Arbil, Iraq

Shadin VI (1956) Life in rivers (Russian). Fizni Presnih Vod SSSR 3:113-256

Sharma RK, Rathore V (2000) Pollution ecology with reference to commercially important fisheries prospects in rural-based water body: the Lake SarsaiNawar, Etawah (Uttar Pradesh). Pollut Res 19:641-644

Sharma A, Sharma RC (2007) Anthwal Monitoring phytoplankton diversity in the hill stream Chandrabhaga in Garhwal Himalayas. Life Sci J 4:80-84
Sharma RC, Arambam R, Sharma R (2009) Surveying macro-invertebrate diversity in Tons River, Doon Valley, India. Environmentalist 29:241-254

Sharma RC, Singh N, Chauhan A (2016) The influence of physicochemical parameters on phytoplankton distribution in a head water stream of Garhwal Himalayas: a case study. Egypt J Aquat Res 42(1):11-21

Sharpley AN (1995) Dependence of runoff phosphorus on soil phosphorus. J Environ Qual 24:920-926

Sharpley AN, Syers JK (1979) Phosphorus inputs into a stream draining an agricultural watershed. II: amounts contributed and relative significance of runoff types. Water Air Soil Pollut 11:417-428

Sheets TJ (1980) Agricultural pollutants. In: Guthrie FE, Perry JJ (eds) Introduction to environmental toxicology. Elsevier North Holland, Inc., New York, pp 24-33

Sheridan WL (1961) Temperature relationships in a pink salmon stream in Alaska. Ecology 42:91-98

Shirazi Mostafa A, Boersman L, Haggerty PK, Johnson CB (2001) Predicting physical and chemical water properties from relationships with watershed soil characteristics. J Environ Qual 30:112-120

Singleton H (2000a) Ambient water quality guidelines for sulphate. Ministry of Environment, Lands and Parks, Victoria

Singleton H (2000b) British Columbia ambient water quality guidelines for sulphate: technical appendix. Ministry of the Environment, Lands and Parks, Water Quality Section. Water Management Branch, Berlin

Sliva L, Williams DD (2001) Buffer zone versus whole catchment approaches to studying land use impact on river water quality. Water Res 35:3462-3472

Small MJ, Sutton MC (1986) A regional pH-alkalinity relationship. Water Resour 20:335-343

Smart RP, Soulsby C, Neal C, Wade A, Cresser MS, Billett MF, Langan SJ, Edwards AC, Jarvie HP, Owen R (1998) Factors regulating the spatial and temporal distribution of solute concentrations in a major river system in NE Scotland. Sci Total Environ 221:93-110

Smith K (1981) The prediction of river water temperature. Hydrol Sci Bull 26(1):19-32

Smith BPG, Hannah DM, Gurnell AM, Petts GE (2001) A hydro geomorphological context for ecological research on alpine glacial rivers. Freshw Biol 46(12):1579-1596

Sutcliffe DW, Carrick TR (1983) Chemical composition of waterbodies in the English Lake District: relationships between chloride and other major ions related to solid geology and a tentative budget for Windermere. Freshw Biol 13:323-352

Sutherland BA, Meyer JL, Gardiner EP (2002) Effects of land cover on sediment regime and fish assemblage structure in four southern Appalachian streams. Freshw Biol 47:1791-1805

Swaney DP, Hong B, Ti C, Howarth RW, Humborg C (2012) Net anthropogenic nitrogen inputs to watersheds and riverine $\mathrm{N}$ export to coastal waters: a brief overview. Curr Opin Environ Sustain 4:203-211

Talling JF (1957) The longitudinal succession of water characteristics in the White Nile. Hydrobiologia 11:73-89

Thomsen AG, Friberg N (2002) Growth and emergence of the stonefly Leuctra nigra in coniferous forest streams with contrasting $\mathrm{pH}$. Freshw Biol 47:1159-1172

Todd LP (1995) Changes in biological characteristics of Daphnia magna from chronic action of copper and nickel at low concentrations. Hydrobiol J 5:59-62

Toma JJ (2000) Limnological study of Dokan Lake, Kurdistan region of Iraq. M.Sc. Thesis, University of Salahaddin, Arbil, Iraq

Townsend CR, Hildrew AG, Francis J (1983) Community structure in some southern streams: the influence of physico-chemical factors. Freshw Biol 13:521-544 
Townsend CR, Doledec S, Norris R, Peacock K, Arbuckle C (2003) The influence of scale and geography on relationships between stream community composition and landscape variables: description and prediction. Freshw Biol 48:768-785

Tucker CS (1984) Carbon dioxide. In: Wellborn TL MacMillan JR Jr (eds) For fish farmers. Mississippi Cooperative Extension Service, $84 \mathrm{pp}$

Turner BL, Baxter R, Ellwood NTW, Brian AW (2003a) Seasonal phosphatase activities of mosses from Upper Teesdale, northern England. J Bryol 25:203-214

Turner RE, Rabalais NN, Justic D, Dortch Q (2003b) Global patterns of dissolved N, P and $\mathrm{Si}$ in large rivers. Biogeochemistry 1:1. https ://doi.org/10.1023/a:1024960007569

Uehlinger U, Malard F, Ward JV (2003) Thermal patterns in the surface waters of a glacial river corridor (Val Roseg, Switzerland). Freshw Biol 48(2):284-300

United States Environment Protection Agency (USEPA) (2000) Freshwater flow and seasonal variation. Technical Support Document, Part B: 1-6

van Vliet MTH, Ludwig F, Zwolsman JJG, Weedon GP, Kabat P (2011) Global river temperatures and the sensitivity to atmospheric warming and changes in river flow. Water Resour Res. https:// doi.org/10.1029/2010WR009198

Vannote RL, Sweeney BW (1980) Geographic analysis of thermal equilibria: a conceptual model for evaluating the effect of natural and modified thermal regimes on aquatic insect communities. Am Nat 115:667-695

Vannote RL, Minshall GW, Cummins KW, Sedell JR, Cushing CE (1980) The river continuum concept. Can J Fish Aquat Sci 37:130-137

Wakida FT, Lerner DN (2006) Potential nitrate leaching to groundwater from house building. Hydrol Process 20(9):2077-2081

Walsh CJ, Fletcher TD, Ladson AR (2005a) Stream restoration in urban catchments through redesigning storm water systems: looking to the catchment to save the stream. J N Am Benthol Soc 24:690-705

Walsh CJ, Roy AH, Feminella Cottingham PD, Groffman PM, Morgan RP (2005b) The urban stream syndrome: current knowledge and the search for a cure. J N Am Benthol Soc 24:706-723

Wang X, Yin Z (1997) Using GIS to assess the relationship between land use and water quality at a watershed level. Environ Int 23:103-114

Wang L, Lyons J, Kanehl P, Gatti R (1997) Influences of watershed land use on habitat quality and biotic integrity in Wisconsin streams. Fisheries 22:6-12

Wang L, Lyons J, Kanehl P, Bannerman R, Emmons E (2000) Watershed urbanization and changes in fish communities in southeastern Wisconsin streams. J Am Water Resour Assoc 36:1173-1189

Wang L, Lyons J, Kanehl P (2001) Impacts of urbanization on stream habitat and fish across multiple spatial scales. Environ Manag 28:255-266

Ward JV (1992) Aquatic insect ecology, biology and habitat. Wiley, New York

Webb BW, Walling DE (1985) Nitrate behavior in streamflow from a grassland catchment in Devon, UK. Water Res 19:1005-1016

Webb BW, Hannah DM, Moore RD, Brown LE, Nobilis F (2008) Recent advances in river and stream temperature. Hydrol Process 22:902-918

Welch PS (1952) Limnology, 2nd edn. McGraw Hill book Company, New York

Wernick BG, Cook KE, Schreier H (1998) Land use and streamwater nitrate-N dynamics in an urban-rural fringe watershed. J N Am Water Resour Assoc 34:639-650

Wetzel RG (2001) Limnology, 3rd edn. Academic Press, San Diego

Wetzel RG, Likens GE (2000) Limnological analyses, 2nd edn. Springer, New York

Wilcock RJ, McBride GB, Nagels JW, Northcott GL (1995) Water quality in a polluted lowland stream with chronically depressed dissolved oxygen: causes and effects. N Z J Mar Freshw Res 29:277-288

William M, Lewis JR, Morris DP (1986) Toxicity of nitrite on fish: a review. Trans Am Fish Soc 115:183-195

Woods W (1965) Physical and chemical limnology of Upper Ohio River. Spec Publ Pyumatuning Lab Field Biol 3:4-44

Xue Y, Song J, Zhang Y, Kong F, Wen M, Zhang G (2016) Nitrate pollution and preliminary source identification of surface water in a Semi-Arid River Basin, using isotopic and hydrochemical approaches. Water 8:328

Yarnell SM, Viers JH, Mount JF (2010) Ecology and management of the spring snowmelt recession. Bioscience 60(2):114-127

Zappa M, Badoux A, Gurtz J (2000) The application of a complex distributed hydrological model in a highly glaciated in alpine river catchment. In: Horvatic J (ed) Limnological Reports, 33rd Conference of the International Association for Danube Research, Osijek, Croatia, 3-9 September, pp 23-28

Publisher's Note Springer Nature remains neutral with regard to jurisdictional claims in published maps and institutional affiliations. 